\title{
POTATO PRODUCTION AS AFFECTED BY CROP PARAMETERS AND METEOROLOGICAL ELEMENTS
}

\author{
André B. Pereira $^{1}$, Nilson A. Villa Nova ${ }^{2}$, Antonio R. Pereira ${ }^{2}$ \\ ${ }^{1}$ Department of Soil Science and Agricultural Engineering, State University of Ponta Grossa. \\ 4748 Carlos Cavalcanti Avenue. 84030-900 Ponta Grossa, PR, Brazil. Phone \#: 005542 \\ 32203090.E-mail address: andre.pereira@pq.cnpq.br \\ ${ }^{2}$ ESALQ/USP, and Brazilian Federal Funding Agency Researcher - CNPq.
}

Abstract: Meteorological elements directly influence crop potential productivity, regulating its transpiration, photosynthesis, and respiration processes in such a way as to control the growth and development of the plants throughout their physiological mechanisms at a given site. The interaction of the meteorological factors with crop responses is complex and has been the target of attention of many researchers from all over the world. There is currently a great deal of interest in estimating crop productivity as a function of climate by means of different crop weather models in order to help growers choose planting locations and timing to produce high yields with good tuber quality under site-specific atmospheric conditions. In this manuscript an agrometeorological model based on maximum carbon dioxide assimilation rates for $\mathrm{C} 3$ plants, fraction of photosynthetically active radiation, air temperature, photoperiod duration, and crop parameters is assessed as to its performance under tropical conditions. Crop parameters include leaf area and harvest indexes, dry matter content of potato tubers, and crop cycles to estimate potato potential yields. Productivity obtained with the cultivar Itararé, grown with adequate soil water supply conditions at four different sites in the State of São Paulo (Itararé, Piracicaba, Tatuí, and São Manuel), Brazil, were used to test the model. The results showed that the agrometeorological model tested under the climatic conditions of the State of São Paulo in general underestimated irrigated potato yield by less than $10 \%$. This justifies the recommendation to test the performance of the model in study in other climatic regions for different crops and genotypes under optimal irrigation conditions in further scientific investigations. We reached the conclusion that the agrometeorological model taking into account information on leaf area index, photoperiod duration, photosynthetically active radiation and air

Please use the following format when citing this chapter:

Pereira, A.B., Villa Nova, N.A. and Pereira, A.R., 2009, in IFIP International Federation for Information Processing, Volume 293, Computer and Computing Technologies in Agriculture II, Volume 1, eds. D. Li, Z. Chunjiang, (Boston: Springer), pp. 495-507. 
temperature is feasible to estimate potential tuber yield at a commercial scale. The performance test shows that it can then be used to forecast harvest time, and also as an effective tool to predict the suitability of potential regions to the cultivation of potato crop, cultivar Itararé, at the State of São Paulo, Brazil.

Keywords: modeling, Solanum tuberosum L., climate, crop indexes, tuber yield

\section{INTRODUCTION}

We considered potential yield to be the maximum possible yield of a given species or cultivar achievable under the existing conditions of solar radiation flux density, with all the other environmental factors considered to be optimal. Therefore, the potential yield is determined by the biological properties of the cultivar and radiation resources available. Potential yield expresses the solar radiation resources for cultivating a given genotype in yield units, whereas the commercial yield is the yield attainable under existing farm conditions that takes into account all the factors limiting the production process and the crop yield.

Meteorological factors directly influence potential crop productivity, regulating its transpiration, photosynthesis, and respiration processes in such a way as to control the growth and development of the plants throughout their physiological mechanisms at a given site. The interaction of the meteorological factors with the crop responses is complex. However, by assessing physiological crop responses to environmental factors under field conditions it is possible to derive mathematical models to estimate crop potential production as a function of climatic variables with a good precision.

Research has been conducted to quantify the effects of the environment on growth, development, and yield of many agronomic crops. Among the main environmental factors that strongly govern all physiological processes of the plants are global solar radiation flux density, air temperature, and available soil water content (Coelho and Dale, 1980).

Potato yield improvements can be obtained by increasing the net daily photosynthetically radiation (PAR) through higher solar irradiance or longer photoperiod (Stuttle et al., 1996). The photoperiod duration doubles from December to June at $50 \mathrm{oN}$, while PAR increases eightfold from 2.11 to 17.01 $\mathrm{MJ} \mathrm{m}^{-2}$ day $^{-1}$ due to higher elevation of the sun above the horizon with lengthening days. Gross carbohydrate production on standard clear days increases from 108 to $529 \mathrm{~kg} \mathrm{ha}^{-1}$ day $^{-1}$ at $50 \mathrm{oN}$, whereas it remains at about $420 \mathrm{~kg} \mathrm{ha}^{-1}$ day $^{-1}$ year-round near the equator. Low solar irradiance is a yield constraint at 30 to $40 \mathrm{oN}$ in fall and spring when potatoes are grown to escape the summer heat (Haverkort, 1990). 
Sarquis et al. (1996) stated that the magnitude of the effect of elevated temperatures on potato growth and final yield is determined by an intricate interaction between soil temperature, air temperature, solar radiation flux density, and photoperiod duration. Their data extended previous observations of the reduction in photosynthesis rate under elevated temperatures (Midmore and Prange, 1992; Manrique and Bartholomew, 1991). Under field conditions reduced dioxide carbon assimilation could not explain the yield reduction observed; the temperature effect on assimilation was not as dramatic as it was on growth or yield. Other workers have reported a severe reduction in the rate of assimilation at air temperatures above $30 \mathrm{oC}$ under controlled experimental conditions. In such cases, reductions in $\mathrm{CO}_{2}$ assimilation rate were shown to correlate well with reductions in growth and yield (Ku et al., 1977; Midmore and Prange, 1992). These results reveal the complexity of plant responses to the combined effects of water and temperature stress, which inevitably occur in association under field conditions (Pereira and Shock, 2006).

Knowledge of climatic requirements of potato and its physiological responses to the environment is extremely important to help growers produce high yields with good tuber quality under site-specific atmospheric conditions. The SUBSTOR-Potato crop soil weather model takes into consideration daily air temperature, photoperiod, intercepted solar radiation, soil water and nitrogen supply. The model simulated fresh tuber yields ranging from $4 \mathrm{t} \mathrm{ha}^{-1}$ to $56 \mathrm{t} \mathrm{ha}^{-1}$ due to differences in weather patterns, soils, cultivars, and management practices (Bowen, 2003).

Kadaja and Tooming (2004) proposed a relatively simple model POMOD to calculate potato yield, which permits integration of the knowledge in different disciplines on the potato crop yield levels, using the measured physiological, ecological, agrometeorological, and agronomical parameters of the plant. The input variables of the model can be divided into four groups: daily meteorological information, annual information, location, and cultivar. The first group includes global radiation, air temperature, and precipitation. The location is characterized by geographical latitude and hydrological parameters. As to cultivar, the parameters of gross and net photosynthesis, the coefficients of growth and maintenance respiration, and albedo of the crop are also needed.

The LINTUL-POTATO simulation model (Kooman and Haverkort, 1995) establishes potential yield of a certain cultivar for a determined growing period and plant density, and is based on incident photosynthetically active radiation (PAR), the fraction of PAR intercepted by the crop, and radiation use efficiency to produce dry matter. Phenological crop development is driven by accumulated degree-days, while development stage determines dry matter partitioning and the pattern of intercepted PAR is defined through 
growth. The potential yield established with this simulation model was used by Caldiz and Struit (1999) to perform a preliminary yield gap analysis regarding actual and attainable potato yield in different areas of Argentina.

We tested the performance of a model based on studies of maximum rates of carbon dioxide assimilation for a $\mathrm{C} 3$ crop as a function of air temperature, a fraction of global solar radiation flux density (PAR), photoperiod duration, and leaf area index to estimate the potential productivity of potato. In order to assess the performance of the proposed mathematical model, the estimated values of tuber yield were compared to observed productivity data under irrigation conditions for the studied sites. The present study was similar to the potential productivity estimation model described by Villa Nova et al. (2001) and employed by Villa Nova et al. (2005) for sugar cane in Piracicaba, SP, Brazil.

\section{MATERIAL AND METHODS}

The proposed model for the estimation of potato potential yield (EPY, $t$ $\mathrm{ha}^{-1}$ ), expressed by equation 1 , is based upon the concept that the maximum rate of dioxide carbon assimilation by the plants for production of carbohydrate $\left(\mathrm{CH}_{2} \mathrm{O}\right)$ is related to the active photosynthetically fraction of the solar spectrum (PAR) and air temperature:

$$
E P Y=1.27 * 10^{-6} * C D A^{*} L A I^{*} G S^{*} N^{*} C(L A I)^{*} C(T) * H I^{* 100} / D M
$$

where CDA is the carbon dioxide assimilation rate $\left(\mu \mathrm{L} \mathrm{cm}^{-2} \mathrm{~h}^{-1}\right)$, LAI is the maximum leaf area index, GS is the number of days of the crop growing season, $\mathrm{N}$ is the mean photoperiod or day length duration throughout of the crop growing season (hours), $\mathrm{C}(\mathrm{LAI})$ is the correction factor for leaf area index variation over time, $\mathrm{C}(\mathrm{T})$ is the correction factor for maintenance respiration, $\mathrm{HI}$ is the harvest index, and DM is the dry matter content of the potato tubers $(\%)$.

Making use of the Clausius-Clapeyron's equation with the masses of $\mathrm{CO}_{2}$ equal to $44 \mathrm{~g} \mathrm{~mol}^{-1}$ and of $\mathrm{CH}_{2} \mathrm{O}$ corresponding to $30 \mathrm{~g} \mathrm{~mol}^{-1}$, and considering $1 \mu \mathrm{L}$ of $\mathrm{CO}_{2}$ at $15 \mathrm{oC}(288 \mathrm{~K})$ and 1 atmosphere equal to $1.863 *$ $10^{-6} \mathrm{~g} \mathrm{CO}_{2}$, one can infer that the $\mathrm{CH}_{2} \mathrm{O} / \mathrm{CO}^{2}$ ratio assumes a value of 1.27 $* 10^{-6}$ of $\mathrm{g} \mathrm{CH}_{2} \mathrm{O} / \mu \mathrm{L} \mathrm{CO}_{2}$ (Villa Nova et al., 2001).

Applying the necessary corrections to the aforementioned equation in order to express the estimates of potato potential yield in tons per hectare per crop cycle, we have:

$$
E P Y=1.27 * 10^{-4} * C D A^{*} L A I * G S^{*} N * C(L A I) * C(T) * H I * 100 / D M
$$


Without considering HI, the product of the other terms of the equation 2 depicts the estimation of the total dry matter produced by the potato plants, including roots, leaves and shoots.

Plotted and interpolated values of CDA were obtained from a graph that shows the relation between air temperature and maximum rate of $\mathrm{CO}_{2}$ assimilation for a $\mathrm{C} 3$ crop species under controlled conditions (Heemst, 1986) as a function of the ambient temperature $(\mathrm{T})$ and photosynthetically active radiation (PAR). However, under field conditions where plants are subjected to fluctuating temperature conditions, there appears to be adaptation of the photosynthetic apparatus. Thus, such plotted and interpolated CDA data are described mathematically by the following equation (Penning de Vries et al., 1989):

$$
C D A=C D A_{\max }\left[1-e^{\frac{-0.5^{*} P A R}{C D A_{\max }}}\right]
$$

where CDAmax is the maximum carbon dioxide assimilation rate of 48 $\mu \mathrm{L} \mathrm{cm}{ }^{-2} \mathrm{~h}^{-1}$.

The photosynthetically active radiation (PAR), expressed in Joule $\mathrm{m}^{-2} \mathrm{~s}^{-1}$, was calculated by the equation proposed by Assunção (1994) as a function of the global solar radiation flux density and insolation ratio:

$$
P A R=\frac{Q g}{3600 * N} *[0.5-0.1 * n / N]
$$

where Qg is the mean global solar radiation flux density throughout the crop growing season (Joule $\mathrm{m}^{-2}$ day $^{-1}$ ), $\mathrm{N}$ is the mean photoperiod during the crop cycle (hours), and $\mathrm{n} / \mathrm{N}$ is the actual mean insolation ratio of the period.

The global solar radiation flux density $(\mathrm{Qg})$ was estimated taking into account the mean values of a and b Angstrom's coefficients obtained by Cervellini et al. (1966) for the State of São Paulo, Brazil. The equation used for the sites where no radiometric measurements were available for the current study was the following:

$$
Q g=Q o[0.24+0.58 * n / N]
$$

where Qo is the extra-terrestrial radiation, expressed in Joule $\mathrm{m}^{-2}$ day $^{-1}$, having been determined by the expression below:

$$
\text { Qo }=38.32 * 10^{6}[h * \sin \delta * \sin \varphi+\cos \delta * \cos \varphi * \sin H]
$$

where $38.32 * 10^{6}$ is the mean value of corrected solar constant converted into Joule $\mathrm{m}^{-2}$ day $^{-1}$, given by Crommelynk and Fichot (1997), $\mathrm{H}$ is the semiarc from the meridian crossing of the sun to sunset in degrees, $h$ is the diurnal semi-arc in radians, $\delta$ is the solar declination in degrees, and $\varphi$ is the local latitude in degrees. 
The equations that defined $\delta, \mathrm{H}$, and $\mathrm{N}$ (Pereira et al., 2003) were:

$$
\delta=23.45 * \sin \left[\frac{360}{365} *(D J-80)\right]
$$

where DJ is the number of days since the first day of January up to the considered date.

$$
\begin{aligned}
& H=\arccos [-\tan \delta * \tan \varphi] \\
& N=\frac{2 * H}{15}
\end{aligned}
$$

The number of hours of insolation (n) was measured with a CampbellStockes sunshine recorder installed at the four weather stations where the studies were carried out.

All the meteorological data used as input variables of the potato potential yield model were obtained from conventional weather stations set up at research locations of the Agronomic Institute of Campinas, IAC, University of São Paulo, ESALQ/USP, and State University of São Paulo, FCA/UNESP. These governmental Institutions of the State of São Paulo provided the necessary meteorological data for the municipalities of Itararé, Tatuí, Piracicaba, and São Manuel, SP, Brazil.

The climate of Tatuí (23o22'S, 47o52'W Gr., and 600m), Piracicaba (22o43'S, 47o25'W Gr., and 580m), and São Manuel (22o44'S, 48o34'W Gr., and $700 \mathrm{~m}$ ) is classified as Cwa or sub-tropical with rains in the summer and dry winter, according to the Köppen System. The climate of Itarare city (24o06'S, 49o20'W Gr., and 1150m) in the State of São Paulo, Brazil, is classified as $\mathrm{Cfb}$ or rainy temperate of altitude, constantly wet throughout the year.

The values of $\mathrm{C}(\mathrm{T})$ equal to 0.6 and 0.5 were adopted, whenever the mean air temperatures throughout the crop-growing season were below or above 20oC, respectively, as recommended by Doorenbos and Kassam (1979). The value of C(LAI) was calculated by the equation described by Villa Nova et al. (2001) as follows:

$$
C(L A I)=\frac{1-e^{-0.8^{*} L A I}}{2}
$$

The ratio between harvested yield and net total dry matter is given by the harvest index (HI) for high-producing cultivars under irrigation. For potato, whose commercial product is the tuber, HI varies from 0.55 to 0.65 (Doorenbos and Kassam, 1979). For practical purposes, we adopted the mean value corresponding to 0.6 to calculate the final crop production.

The maximum leaf area index (LAI) for the cultivar Itarare (IAC-5986) was determined experimentally in the field by Varillas (1991) and Robles (2003) under the climatic conditions of Itararé and Piracicaba. 
The dry matter content of the tubers is intimately related to the tuber specific gravity. To measure tuber specific gravity the weight-in-air/weightin-water method was used. For that, a random sample of tubers was first weighed in air (Wair) and, after submerging the tubers in water, weighed again (Wwater). Thus, specific gravity (SG) was calculated using the following formula (Stark and Love, 2003):

$$
S G=\frac{W_{\text {air }}}{W_{\text {air }}-W_{\text {water }}}
$$

Dry matter content of the tubers in percentage, was determined by the expression described by Ramos (1999) as a function of the specific gravity as follows:

$$
D M=24.182+211.04 *[S G-1.0988]
$$

The calculated values of the potential yield obtained by the proposed method were correlated with the observed data from the production fields. Since the coefficients of correlation and determination are not always suitable to evaluate the performance of a model, the agreement index $d$ was also used (Willmott et al., 1985). The index c proposed by Camargo and Sentelhas (1995) was also adopted in this paper to indicate the performance of the model, putting together the accuracy $\mathrm{R}$ and the exactness $\mathrm{d}$ indices, being defined as the product of both indices.

The values of the tuber specific gravity and dry matter content were obtained by the researchers from the Agronomic Institute of Campinas IAC - at all the locations where the potato experiments were conducted from 1985 to 2005 (data not published).

\section{RESULTS AND DISCUSSION}

Potato potential yield for the cultivar Itarare was calculated throughout fifteen site-years at four different regions of the State of São Paulo, Brazil (Tables 1 and 2) using of the mean values of global solar radiation flux density, photoperiod duration, photosynthetically active radiation, air temperature, and the maximum rates of carbon dioxide assimilation obtained from equation 3, which are the required input variables of the proposed model.

Tuber potential yields calculated by the agrometeorological model in study and potential yields harvested from the production fields were highly correlated, since the statistical analysis shows that over $92 \%$ of the potential yield variations can be explained by the calculated values. The corresponding values of fresh tuber yields estimated by the model varied 
from 16.8 to $35.7 \mathrm{t} \mathrm{ha}^{-1}$, whereas those of fresh tuber yields obtained from the production areas with an adequate soil water supply were within the range varying from 17.5 to $39.0 \mathrm{t} \mathrm{ha}^{-1}$ (Table 2). The larger difference between measured and estimated tuber yield was observed for the growing period September through January of the years 1998 and 2003, when the model slightly underestimated and overestimated potential yield at 3.3 and $3.5 \mathrm{t} \mathrm{ha}^{-1}$, respectively.

Table 1. Meteorological data throughout different years and growth periods of the potato crop, cultivar Itararé (IAC-5986), grown at Itararé, Tatuí, Piracicaba, and São Manuel, State of São Paulo, Brazil.

\begin{tabular}{cclcccccc}
\hline Site & Year & $\begin{array}{c}\text { Growth } \\
\text { period }\end{array}$ & $\begin{array}{c}\text { Cycle } \\
(\text { days })\end{array}$ & $\begin{array}{c}\mathrm{T} \\
(\mathrm{oC})\end{array}$ & $\mathrm{n} / \mathrm{N}$ & $\begin{array}{c}\mathrm{Qg} \\
\left(\mathrm{J} \mathrm{m}^{-2} \mathrm{~s}^{-1}\right)\end{array}$ & $\begin{array}{c}\mathrm{PAR} \\
\left(\mathrm{J} \mathrm{m}^{-2} \mathrm{~s}^{-1}\right)\end{array}$ & $\begin{array}{c}\mathrm{P} \\
(\mathrm{mm})\end{array}$ \\
\hline \multirow{6}{*}{ Itararé } & 1985 & Mar./Jun. & 100 & 16.5 & 0.57 & 395.0 & 176.3 & 587 \\
& 1993 & Sep./Jan. & 137 & 18.0 & 0.45 & 429.8 & 194.4 & 809 \\
& 1994 & Mar./Jul. & 114 & 16.0 & 0.54 & 382.5 & 170.0 & 572 \\
& 1997 & Feb./Jul. & 140 & 16.5 & 0.57 & 411.0 & 181.1 & 596 \\
& 1998 & Apr./Aug. & 112 & 15.0 & 0.57 & 378.3 & 167.9 & 505 \\
& 1999 & Sep./Jan. & 117 & 18.0 & 0.33 & 372.0 & 173.5 & 1163 \\
& 2000 & Mar./Jul. & 126 & 15.6 & 0.55 & 388.0 & 172.8 & 578 \\
& 2001 & Mov./Mar. & 133 & 20.2 & 0.49 & 452.1 & 204.1 & 818 \\
& 2003 & Sep./Jan. & 102 & 16.9 & 0.55 & 392.2 & 173.5 & 549 \\
Tatuí & 2005 & Mar./Jul. & 133 & 17.5 & 0.43 & 415.9 & 188.8 & 865 \\
\cline { 2 - 9 } Piracicaba & 2005 & Oct./Feb. & 122 & 18.7 & 0.48 & 400.6 & 177.0 & 508 \\
n. Manuel & 2001 & Sep./Jan. & 115 & 22.8 & 0.55 & 413.8 & 190.2 & 935 \\
\cline { 2 - 9 } & 1989 & Oct./Feb. & 105 & 23.6 & 0.58 & 503.0 & 212.5 & 723 \\
\hline
\end{tabular}

$T=$ daily air temperature; $n / N=$ insolation ratio; $Q g=$ global solar radiation density flux; and $P A R=$ photosynthetically active radiation; $P=$ total of rainfall throughout the crop growing season. Monthly average values.

Table 2. Cultivar characteristics throughout different years and growth periods of the potato crop, cultivar Itararé (IAC-5986), grown at Itararé, Tatuí, Piracicaba, and São Manuel, State of São Paulo, Brazil, and the respective potential yield data.

\begin{tabular}{ccccccccccc}
\hline Site & Year & Growthperiod & CDA & LAI & C(LAI) & C(T) & HI & DM & EPY & MPY \\
\hline \multirow{6}{*}{ Itararé } & 1985 & Mar./Jun. & 41.0 & 4.34 & 0.480 & 0.6 & 0.6 & 25.0 & 17.5 & 17.5 \\
& 1993 & Sept./Jan. & 41.5 & 4.34 & 0.480 & 0.6 & 0.6 & 25.0 & 27.9 & 26.4 \\
& 1994 & Mar./Jul. & 41.0 & 4.34 & 0.480 & 0.6 & 0.6 & 17.8 & 27.8 & 28.2 \\
& 1997 & Feb./Jul. & 41.0 & 4.34 & 0.480 & 0.6 & 0.6 & 18.9 & 32.9 & 30.8 \\
& 1998 & Apr./Aug. & 41.0 & 4.34 & 0.480 & 0.6 & 0.6 & 22.3 & 21.4 & 20.3 \\
& 1999 & Sep./Jan. & 41.0 & 4.34 & 0.480 & 0.6 & 0.6 & 16.5 & 35.7 & 39.0 \\
& 2000 & Mar./Jul. & 41.0 & 4.34 & 0.480 & 0.6 & 0.6 & 17.8 & 30.7 & 31.6 \\
& 2001 & Mar./Jur. & 42.0 & 4.34 & 0.480 & 0.5 & 0.6 & 18.0 & 32.0 & 31.5 \\
& 2003 & Sep./Jan. & 41.0 & 4.34 & 0.480 & 0.6 & 0.6 & 22.3 & 19.8 & 19.5 \\
& 2005 & Mar./Jul. & 41.5 & 4.34 & 0.480 & 0.6 & 0.6 & 16.8 & 29.7 & 26.2 \\
Tatuí & 2005 & Oct./Feb. & 41.5 & 4.34 & 0.480 & 0.6 & 0.6 & 22.3 & 25.9 & 25.2 \\
\cline { 2 - 10 } Piracicaba & 2001 & Sep./Jan. & 46.7 & 4.34 & 0.480 & 0.6 & 0.6 & 19.7 & 32.0 & 32.7 \\
\cline { 2 - 10 } S. Manuel & 1989 & Oct./Feb. & 47.7 & 2.50 & 0.423 & 0.5 & 0.6 & 17.8 & 30.9 & 29.2 \\
\hline
\end{tabular}


$C D A=$ Carbon dioxide assimilation maximum rates $\left(\mu L \mathrm{~cm}^{-2} h^{-1}\right) ; L A I=$ leaf area index (maximum value); $C(L A I)=$ correction factor for leaf area index variation; $C(T)=$ correction factor for maintenance respiration; $H I=$ harvest index; $D M=$ dry matter content (\%); EPY = estimated crop potential yield $\left(t h a^{-1}\right) ; M P Y=$ measured crop potential yield $\left(t h a^{-1}\right)$.

In the most important potato production areas of Argentina, Caldiz and Struit (1999) reported that actual fresh tuber yields vary from 13 to $30 \mathrm{tha}^{-1}$, whereas potential yields estimated by the LINTUL-POTATO simulation model ranged from 47 to $126 \mathrm{t} \mathrm{ha}^{-1}$. Differences between actual and potential yield might be attributed to suboptimal solar radiation interception by the foliage, cultivar, seed management, physiological age of the seed, suboptimal management of water and fertilizer, and inadequate control measures for early blight and late blight.

The potential yield of agronomic crops is dramatically affected by the amount of water applied during the crop-growing season at a given region. Water and temperature are important climatic factors to consider in crop modelling studies. Cooler temperatures result in delayed maturity, which provides more time for the interception of solar radiation and conversion of intercepted radiation into dry matter. Stark and Love (2003) point out that two major factors influence tuber yield: a) photosynthetic activity and duration of the leaf canopy, and b) the length of the linear tuber growth phase. The longer a canopy is able to produce photosynthate at a relatively high rate, and the longer tubers are bulking at their maximum rate, the higher the yield will be in such a way as to express the productive potentiality of potato crop at a given site.

As to the effect of water application on the productive potentiality expression of potato in a determined climatic locality, Bowen (2003) reported that a reduction of only $62 \mathrm{~mm}$ in water applied resulted in a decrease in fresh tuber yield from 38.2 to $30.3 \mathrm{t} \mathrm{ha}^{-1}$. For the summer potato crop, applied water ranged from 380 to $584 \mathrm{~mm}$ and the associated yields ranged from 12.1 to $25.4 \mathrm{t} \mathrm{ha}^{-1}$. Therefore, about half as much water was used during the winter to produce $150 \%$ more yield than was obtained throughout the summer crop-growing season.

The differences observed on the dry matter content throughout different years and growth periods of the potato crop (Table 2) might be ascribed to climatic variations on tuber specific gravity. Apart from the primary environmental factors affecting specific gravity of irrigated potatoes (air and soil temperatures), other weather conditions can also affect tuber specific gravity.

Stark and Love (2003) state that high evaporative demand caused by low relative humidity, high global solar radiation flux density, and/or high wind speed can reduce photosynthesis by causing stomata to close with an accompanying restriction of $\mathrm{CO}_{2}$ uptake. Prolonged periods with overcast 
skies can also reduce light intensity to levels below that required for maximum dry matter production.

The coefficient of determination R2 and correlation R bring information about the degree of accuracy, but do not reveal the exactness of the model. The index of agreement $d$ equal to 0.981 reveals a high level of exactness. The index c was 0.945 for the studied sites, showing an excellent model performance, according to the interpretation reported by Camargo and Sentelhas (1995). Both the model accuracy, given by the trend line, and the model exactness shown by the dispersion of the data around the fitted 1:1 line, were outstanding (Figure 1). The value of $\mathrm{c}$ was higher than 0.93, exceeding, therefore, the values of $\mathrm{d}$ considered as satisfactory. The lower limit for the index c recommended by Robinson and Hubbard (1990) is 0.75 .

The results showed that the agrometeorological model tested under the climatic conditions of the State of São Paulo, Brazil, in general underestimated irrigated potato yield by less than $10 \%$. This justifies the recommendation to test the performance of the model in other climatic regions, for different crops and genotypes under optimal irrigation conditions in further scientific investigations.

Given the excellent performance of the model we suggest that it can be used to forecast harvest time, or be used as an effective tool to predict the suitability of potential regions to the cultivation of potato crops, cultivar Itararé (IAC-5986), in the State of São Paulo, Brazil.

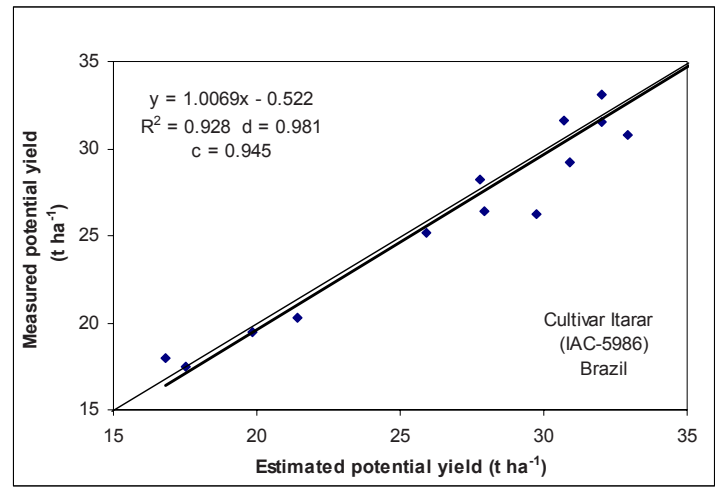

Fig. 1. Relation between observed and predicted potential potato tuber yield, cultivar Itararé (IAC-5986), for the State of São Paulo, Brazil.

\section{CONCLUSIONS}

The agrometeorological model taking into account information on leaf area index, photoperiod duration, photosynthetically active radiation and air temperature is feasible to estimate potential tuber yield at a commercial scale. 


\section{ACKNOWLEDGEMENTS}

The access to the meteorological data provided by the Agrometeorology Division of the Instituto Agronômico de Campinas - IAC - by means of Dr. Orivaldo Brunini and Dr. Mario J. Pedro Junior is greatly appreciated. Many thanks are owed to the Conselho Nacional de Desenvolvimento Científico e Tecnológico $-\mathrm{CNPq}$ - for the provision of the productivity scholarship, as well as to MSc. Sandy Shelton from San Francisco, CA, USA, for the thorough revision on the English of the current manuscript.

\section{REFERENCES}

Assunção, H.F. 1994. Relações entre radiação fotossinteticamente ativa e radiação solar global em Piracicaba, SP. Piracicaba, Dissertation (MSc.), 58p. Escola Superior de Agricultura "Luiz de Queiroz", Universidade de São Paulo.

Bowen, W.T. Water productivity and potato cultivation. 2003. In: Kijne, J.W.; Barker, R.; Molden, D. (eds.) Water Productivity in Agriculture: Limits and Opportunities for Improvement. CAB International 2003. p.229-238. Available on-line at:

http://www.iwmi.cgiar.org/pubs/Book/CA_CABI_Series/Water_Productivity/Protected/0851 996698ch14.pdf.

Caldiz, D.O.; Struit, P.C. 1999. Survey of potato production and possible yield constraints in Argentina. Potato Research 42:51-71.

Camargo, A.P.; Sentelhas, PC. 1995. Avaliação de modelos para estimativa da evapotranspiração potencial mensal em base diária para Campinas e Ribeirão Preto, SP. In: Congresso Brasileiro de Agrometeorologia, Vol. 7, Anais... Campina Grande, p. 415-417.

Cervellini, A.; Salati, E., Godoy, H. 1966. Estimativa da distribuição da energia solar no Estado de São Paulo. Bragantia 25:31-40.

Coelho, D.T.; Dale, R.F. 1980. An energy-crop growth variable and temperature function for predicting corn growth and development. Planting to silking. Agronomy Journal 72: 503510.

Crommelynk, D.; Fichot, A. 1997. Solar constant temporal and frequency characteristics. Royal Meteorological Institute of Belgium, Bruxelas. Available on-line at:

http://estirm2.oma.be/solarconstant/sarr/sarr.html

Doorenbos, J.; Kassam, A.H. 1979. Yield response to water. Rome: FAO, 193p. (Irrigation and Drainage Paper, 33).

Haverkort, A.J. 1990. Ecology of potato cropping systems in relation to latitude and altitude. Agricultural Systems 32: 251-272.

Heemst, H.D.J. van. 1986. Physiological principles. In: Keulen, H. van; Wolf, J. Modelling of agricultural production: weather, soils and crops. Wageningen: Pudoc, p.13-26.

Kadaja, J.; Tooming, H. 2004. Potato production model based on principle of maximum plant productivity. Agricultural and Forest Meteorology 127:1-16.

Ku, S.B.; Edwards, G.E.; Tanner, C.B. 1977. Effects of light, carbon dioxide, and temperature on photosynthesis, oxygen inhibition of photosynthesis, and transpiration in Solanum tuberosum. Plant Physiology 59:868-872. 
Manrique, L.A.; D.P. Bartholomew. 1991. Growth and yield performance of potato grown at three elevations in Hawaii: II. Dry matter production and efficiency of partitioning. Crop Science 31:367-372.

Midmore, D.J.; Prange, R.K. 1992. Growth responses of two Solanum species to contrasting temperatures and irradiance levels: relations to photosynthesis, dark respiration and chlorophyll fluorescence. Annuals of Botany 69:13-20.

Penning de Vries, F.W.T.; Jansen, D.M.; Jen Berge, H.F.M.; Bakema, A. 1989. Simulation of ecophysiological process of growth in several annual crops. Wageningen, PUDOC. 271p.

Pereira, A.B.; Shock, C.C. 2006. Development of irrigation best management practices for potato from a research perspective in the United States. Sakia.org e-publish 1:1-20. Available on-line at: http://www.sakia.org/

Pereira, A.B.; Villa Nova, N.A.; Galvani, E. 2003. Estimation of global solar radiation flux density in Brazil from a single measurement at solar noon. Biosystems Engineering 86:2734. Available on-line at: http://www.sciencedirect.com

Ramos, V.J. 1999. Produção e qualidade da batata (Solanum tuberosum spp. tuberosum), cv. Itararé (IAC-5986) em função do peso do tubérculo semente, densidade de plantas e adubação. Botucatu, Thesis $(\mathrm{PhD}), 127 \mathrm{p}$. Faculdade de Ciências Agronômicas, Universidade Estadual Paulista.

Robles, W.G.R. 2003. Dióxido de carbono via fertirrigação em batateira (Solanum tuberosum L.) sob condições de campo. Piracicaba, Thesis (PhD), 160 p. Escola Superior de Agricultura "Luiz de Queiroz", Universidade de São Paulo.

Robinson, J.M.; Hubbard, K.G. 1990. Soil water assessment model for several crops in high plains. Agronomy Journal 82:1141-1148.

Sarquis, J.I., Gonzalez, H.; Bernal-Lugo, I. 1996. Response of two potato clones (Solanum tuberosum L.) to contrasting temperature regimes in the field. American Potato Research 73:285-300.

Stark, J.C.; Love, S.L. Tuber Quality. 2003. In: Stark, J.C.; Love, S.L. (Co-editors) Potato Production Systems. University of Idaho Extension, Moscow, p.329-343.

Stuttle, G.W.; Yorio, N.C.; Wheeler, R.M. 1996. Interacting effects of photoperiod and photosynthetic photon flux on net carbon assimilation and starch accumulation in potato leaves. Journal of the American Society of Horticultural Science 121:264-268.

Sun, D.; Dickinson, G.R. 1997. Early growth of six native Australian tree species in windbreaks and their effect on potato growth in tropical northern Australia. Forest Ecology Management 95:21-34..

Varillas, I.T. 1991. Determinação de unidades térmicas e avaliação dos efeitos de níveis térmicos elevados sobre o crescimento e a produção de cultura de batata (Solanum tuberosum L.). Piracicaba, Dissertation (MSc.), 62 p. Escola Superior de Agricultura "Luiz de Queiroz", Universidade de São Paulo.

Villa Nova, N.A.; Santiago, A.V.; Rezende, F.C. 2001. Energia Solar. Aspectos físicos de captura pela biomassa. Departamento de Ciências Exatas: Escola Superior de Agricultura Luiz de Queiroz, Universidade de São Paulo, 20p.

Villa nova, N.A.; Pilau, F.G.; Dourado Neto, D.; Manfron, P.A. 2005. Estimativa da produtividade de cana-de-açúcar irrigada com base na fixação de $\mathrm{CO} 2$, radiação solar e temperatura do ar. Revista Brasileira de Agrometeorologia 13:405-411.

Willmott, C.J.; Ackleson, S.G.; Davies, R.E.; Feddema, J.J.; Klink, K.M.; Legates, D.R.; O'Donnell, J.; Rowe, C.M. 1985. Statistics for the evaluation and comparison of models. Journal of Geophysical Research 90:8995-9005. 
Uehara, G. 1985. The International Benchmark Sites Network for Agrotechnology Transfer (IBSNAT). Wheat Growth and Modelling. Proceedings of a NATO Advanced Research Workshop. 271-274.

XIE Wenxia,YAN Lijiao,WANG Guanghuo. 2006. Simulation and Validation of Rice Potential rowth Process in Zhejiang by Utilizing WOFOST Model. Chinese Rice Sci. 20(3):319 32.

Xuzhang Xue, Larry C Munn. 2003. Soil Survey Results in Xiaotangshan Station. 